\title{
EVROPSKA BANKARSKA UNIJA KAO DEO POSTKRIZNOG SISTEMA UPRAVLJANJA EKONOMSKOM I MONETARNOM UNIJOM
}

\author{
Dragana DABIĆ \\ Branimir GAJIĆ*
}

\begin{abstract}
Apstrakt: U radu se ispituje pretpostavka da projekat izgradnje Evropske bankarske unije predstavlja najznačajniji transfer ekonomskih nadležnosti na Evropsku uniju još od odluke o centralizaciji monetarne politike. Cilj rada je dvojak. Prvi cilj je predstaviti arhitekturu Bankarske unije, uglavnom na osnovu izvora evropskog prava. Drugi cilj se ogleda u razmatranju širih implikacija integrisanog finansijskog okvira, u prvom redu očekivanja u pogledu dalje centralizacije nadležnosti na nivou Unije. Do sada su postavljena prva dva stuba konstrukcije Bankarske unije Jedinstveni mehanizam nadzora i Jedinstveni mehanizam sanacije banaka. Za Bankarsku uniju, kakva je na delu, ne može se reći da je ostvarila ciljeve zacrtane od strane evropskih državnika i zvaničnika Unije, jer je još uvek nepotpuna. Kako bi bila dovršena potrebno je postaviti i njen treći stub - Evropski (naddržavni) mehanizam osiguranja depozita. Zaključuje se da će u budućnosti ovaj projekat biti poprište daljih institucionalnih reformi u smeru ka „pravoj” Ekonomskoj i monetarnoj uniji. Način na koji će definitivno biti uobličen sistem upravljanja u zoni evra, kako odnosi između centralnog nivoa i država članica (federalno načelo nasuprot povratku na niže nivoe integracije) tako i odnosi između samih članica (načelo demokratske jednakosti nasuprot nedemokratskog obrasca nadređenosti i podređenosti), presudno će uticati na budućnost evropskog projekta ujedinjenja. Preduzimanje daljih koraka u cilju legitimizacije odnosa između političkih aktera,
\end{abstract}

\footnotetext{
* Dragana Dabić, istrživač-saradnik u Institutu za međunarodnu politiku i privredu u Beogradu, e-mail: ddabic@diplomacy.bg.ac.rs.

Rad je nastao u okviru naučnoistrživačkog projekta „Srbija i izazovi u međunarodnim odnosima 2020. godine", koji finansira Ministarstvo prosvete, nauke i tehnološkog razvoja Republike Srbije, a realizuje Institut za međunarodnu politiku i privredu tokom 2020. godine. Branimir Gajić, pomoćnik ministra u Sektoru za praćenje fiskalnih rizika, Ministarstvo finansija Republike Srbije.

Stavovi izneti u članku odražavaju lični stav autora, a ne institucije u kojoj je zaposlen.
} 
funkcionisanja institucija i nedovoljno transparentnih procesa naddržavnog odlučivanja je nužno.

Ključne reči: Ekonomska i monetarna unija, Bankarska unija, kriza Evropske unije, postkrizni sistem upravljanja, Evropska centralna banka, naddržavno, ekonomsko upravljanje, tehnokratsko upravljanje, demokratski deficit, legitimitet

\section{1) UVOD}

U strategiji zvučnog naziva „Ka pravoj Ekonomskoj i monetarnoj uniji” izneta je vizija (ili skiciran politički plan) razvoja „, istinske” Ekonomske i monetarne unije (EMU). ${ }^{1}$ Stabilna i funkcionalna EMU bi prema tadašnjem predsedniku Evropskog saveta trebalo da se zasniva na četiri stuba: integrisanom finansijskom okviru, integrisanom budžetskom okviru, integrisanoj ekonomskoj politici, i poslednje, mada ni u kom slučaju najmanje važno imajući u vidu dugogodišnje zamerke zainteresovane javnosti u pogledu deficitirnih demokratskih praksi Evropske unije (EU, Unija), a koje su sa postepenom konsolidacijom postkriznog poretka samo ojačale - demokratski legitimitet i odgovornost donosioca odluka u sferi naddržavnog ekonomskog upravljanja. U fokusu autora je pomenuti prvi stub „prave” EMU, odnosno Evropska bankarska unija, kako je postalo ubičajeno da se danas označava. Bankarska unija u najkraćem podrazumeva prenošenje institucionalnog i regulatornog okvira na evropski nivo, sa namerom da se osigura stabilnost bankarskog sektora.

Cilj rada je dvojak. Polazeći od izvora prava EU biće predstavljen, po većini ocena, najznačajniji ekonomski poduhvat Unije nakon integrisanja monetarne politike. Nakon toga, razmatraju se šire implikacije osnivanja nadnacionalne Bankarske unije, u prvom redu očekivanja u pogledu dalje centralizacije nadležnosti. Rad sadrži osvrt na predloge (do)gradnje naddržavne EMU. Ističe se kako napredovanje centralizacije ekonomskog upravljanja na nivou Unije, uzrokovano zajedničkim merama zarad suzbijanja efekata krize u Evrozoni, nije ishodilo demokratizacijom istog. Zahvaljujući preduzetim antikriznim merama (prevladavanje volje najjačih država članica uz institucionalne inovacije i prilagođavanje) određeni vid ekonomske stabilnosti je postignut. Da li je sistem zadobio stabilnost na kraći ili srednji rok, ostaje da se vidi. Međutim, dalji koraci u smeru legitimizacije političkih aktera, institucija i nedovoljno transparentnih procesa naddržavnog odlučivanja su nužni.

\footnotetext{
1 "Towards a genuine economic and monetary union", Report by President of the European Council Herman Van Rompuy, Brussels, 26 June 2012.
} 


\section{2) EVROPSKI POSTKRIZNI EKONOMSKI POREDAK}

Nova institucionalna arhitektura evropskog ekonomskog upravljanja, nastala kao odgovor na svetsku finansijsku krizu, postepeno se uobličavala tokom poslednje decenije. Navedena vremenska odrednica je samo uslovna, jer je proces izgradnje „prave”, odnosno funkcionalne EMU, još uvek u toku. Kako se predmet rada odnosi pre svega na postkrizni sistem upravljanja evropskom ekonomijom, analiza uzroka, pojavnih oblika i toka krize na evropskom tlu, kao i mnogobrojnih antikriznih mera biće izostavljena. ${ }^{2} \mathrm{Na}$ ovom mestu će sumarno biti predstavljene konture novog poretka i osvetljeni najvažniji problemi koji generišu pozive ka daljoj reformi sistema.

Do sada su izvršene reforme u ključnim oblastima makroekonomskog upravljanja: monetarnoj i fiskalnoj politici, kao i politici finansijske stabilnosti. Ipak, mere Evropske centralne banke (ECB) pokazale su se presudnim za prevazilaženje akutne faze krize u kojoj je i sam opstanak projekta monetarne integracije bio doveden u pitanje. Dok su ekonomisti uglavnom hvalili odlučnost ECB i isticali efikasnost njenih mera, pravnici i politikolozi su diskutovali o tome da li je ona prekoračila svoje normativno ustanovljene nadležnosti i koje su posledice. ${ }^{3} \mathrm{U}$ nedostatku institucionalnih i političkih alternativa, ECB je morala da „spasi” evro, otkupom državnih obveznica koje investitori više nisu želeli, preuzimajući tako na sebe ulogu „kreditora u poslednjoj instanci” (lender of last resort). Pri tome je koncepcija EMU, uvedena Ugovorom iz Mastrihta, pretrpela suštinske izmene. Naime, centralna banka koja vrši pomenutu funkciju „poslednjeg finansijskog utočišta" za banke koje su zapale u probleme, a u odsustvu formalnih ovlašćenja da ih „disciplinuje” ili dobije „supervizorske” informacije u vezi sa njihovim poslovanjem, rizikuje moralni hazard. ${ }^{4}$ Može se reći da su evropski državnici i zvaničnici EU uočili potencijalne implikacije i uspeli da postignu kompromisni dogovor o Bankarskoj uniji.

Nesporno je da su se sve velike centralne banke u svetu zahvaljujući primeni mera nestandardnog monetarnog regulisanja pokazale izrazito uspešnim u „kupovini vremena” i zauzdavanju najtežih posledica finansijske krize. Sledeći korak

\footnotetext{
${ }^{2}$ Detaljnije o ovome videti u: Miroslav Antevski, Stevan Rapaić, „Kriza u Evrozoni i evropska integracija”, Evropsko zakonodavstvo, God XIII, br. 47-48, str. 92-121; kao i Dragana Dabić, „Kriza Evrozone i dosadašnji odgovori Evropske unije”, Evropsko zakonodavstvo, godina XIII, br. 47/48, 2014, str. 139-161.

3 „Glavna briga ECB je, umesto nekadašnje stabilnosti cena, sada postala - omogućiti sam opstanak monetarne unije." Giandomenico Majone, Rethinking the Union of Europe Postcrisis: Has Integration Gone Too Far?, Cambridge University Press, 2014, p. 54.

${ }^{4}$ Moralni hazard upućuje na situaciju u kojoj ponašanje jedne strane ugrožava dobrobit druge strane (ili vrši neku eksternaliju na tu drugu stranu), pri čemu to ponašanje ne može biti nekim zajedničkim dogovorom unapred precizirano tako da to bude pouzdano. Žan Tirol, Ekonomija za opšte dobro, Akademska knjiga, Novi Sad, 2019, str. 338.
} 
koji je trebalo preduzeti u zoni evra sastojao se u reformama kojima bi se obezbedila dugoročna stabilnost. Najvažniji ekonomski zadatak države - stvaranje optimalnih strukturnih uslova za privredni rast, razvoj i napredak - leži na vladi, a ne na centralnoj banci. A, to je upravo ono što sadašnjoj evrozoni tako očito nedostaje. Ono što je danas na delu jeste institucionalni okvir koji još uvek nije definitivno zaokružen. Razlikuje se u odnosu na period od pre krize (sistem je centralizovaniji sa većim ovlašćenjima ECB i Komisije), s jedne strane, ali i od primera fiskalnog federalizma, s druge strane. Još uvek nije dosegnut ni stepen integracije naznačen u programskim dokumentima čelnika EU na putu ka „pravoj” EMU.

Institucionalna logika u osnovi evropske posleratne politike sugeriše da će se države okrenuti kreiranju zajedničkih institucija i prenošenju nadležnosti na iste u slučajevima kada same ne mogu da ostvare željeni cilj ili korist. Jedna od stavki koja naddržavni režim EU razlikuje od većine međunarodnih aranžmana jeste nadređenost nadnacionalnog autoriteta u utvrđenim oblastima delovanja. Konstitutivne države EU povinuju se odlukama nadnacionalnih institucija, čak i kada im to ne ide u prilog. Nigde to nije očiglednije nego u zoni evra zahvaćenoj vrtlogom krize. ${ }^{5}$ Okosnicu novog ekonomskog poretka čini delikatni amalgam međuvladinog sporazumevanja sa presudnom ulogom najjačih članica, uz istovremenu centralizaciju ekonomskih politika koja je omogućena delovanjem nadnacionalnih institucija. ${ }^{6}$ Došlo je do prilagođavanja postojećih funkcija institucija kada je to bilo moguće (npr. nove uloge ECB u sistemu i pooštrena nadzorna funkcija Komisije, a vredno je ispitati i eventualnu „političku” ulogu Suda pravde EU u legitimizaciji evropskih odgovora na krizu), kao i ustanovljavanja novih aranžmana sporazumima država članica u cilju izbegavanja izmene Osnivačkih akata (osnivanje Evropskog stabilizacionog mehanizma, usvajanje tzv. Fiskalnog pakta, ${ }^{7}$ stvaranje fonda za sanaciju evropskih banaka).

Teoretičari koji na kritičkim osnovama pristupaju analizi postkriznog sistema nalaze da su mere za spas zajedničke valute ostavile nepovoljne posledice po demokratski legitimitet poretka u zoni evra. Kriza i evropski odgovori na nju uslovili su raslojavanje između država "kreditora” i država „dužnika”, rezultirajući osetnim gubitkom autonomije potonjih. Time je doveden u pitanje jedan od osnovnih principa integracije - demokratska jednakost svih članica. Dalje, (zlo)upotreba instituta vanrednih mera, netransparentnost odlučivanja, zamagljivanje odgovornosti aktera, samo su neke od karakteristika novouspostavljenog

\footnotetext{
${ }^{5}$ U današnjoj EU sve je teže povući granicu do koje seže dobrovoljni pristanak država članica da se povinuju nadnacionalnom autoritetu. Tako, npr. iako socio-ekonomsko odlučivanje nije preneto na nivo EU, „dužnici” unutar Evrozone su se suočili sa gotovo potpunim gubitkom autonomije ne bi li dobili finansijsku pomoć.

${ }^{6}$ Izuzimajući Evropski parlament, jedinu instituciju izabranu od strane evropskih građana.

${ }^{7}$ Ugovor o stabilnosti, koordinaciji i upravljanju Ekonomskom i monetarnom unijom.
} 
nadnacionalnog ekonomskog poretka koje su identifikovane u literaturi. Pored toga, uveliko se razmatra da li je nadnacionalni nivo vlasti prekoračio nadležnosti koje su mu poverene Osnivačkim aktom. ${ }^{8}$ Profesor Samardžić je stava da je reč o poretku u permanentnoj krizi koji je zadobio obeležja autoritarnosti u unutrašnjim odnosima. ${ }^{9}$ Složene strukture, još uvek neuobličena (na pola puta između stabilnijih poznatih formi ekonomskog upravljanja) i upitne demokratske legitimnosti, postkrizna EMU je polazište za dalja razmatranja unutar različitih disciplina. Način na koji će definitivno biti uobličen sistem upravljanja u zoni evra, kako odnosi između centralnog nivoa i država članica (federalno načelo nasuprot povratku na niže nivoe integracije) tako i odnosi između samih članica (načelo demokratske jednakosti nasuprot nedemokratskog obrasca nadređenosti i podređenosti), presudno će uticati na budućnost evropskog projekta ujedinjenja.

\section{3) POTREBA ZA EVROPSKOM BANKARSKOM UNIJOM10}

„Evropske banke su bile evropske tokom života, a nacionalne u smrti."11

Osnivački ugovori (inicijalno Mastrihtski ugovor, a potom i njegove izmene zaključno sa važećim Lisabonskim ugovorom) ostavili su ECB bez mogućnosti prudencione kontrole (kontrole boniteta i poslovanja) velikih kreditnih institucija. Tokom krize zajedničke institucije nisu mogle mnogo da učine da stave tačku na svojevrsni „začarani krug” između vlada i nacionalnih banaka, odnosno da spreče negativne efekte na fiskalnu poziciju države kada bi ova intervenisala da pomogne bankama zapalim u probleme. Naime, iako je ustanovljenje jedinstvenog tržišta bankama omogućilo da nude finansijske usluge mimo nacionalnih granica, širom EU, odgovornost za kontrolu nad tim bankama u krajnjem je padala na nacionalne regulatorne institucije. U dobrim vremenima integracija evropskih finansijskih tržišta i zajednička valuta podsticali su rast profita banaka u Evrozoni. Ali, kako to

\footnotetext{
${ }^{8}$ EU je morala da se odluči za kršenje sopstvenih pravila kada je krenula u pomoć Grčkoj. Isto važi i za ECB, koja je otkupila javni dug zemalja u teškoćama prihvatajući kolateral niske vrednosti. Žan Tirol, Ekonomija za opšte dobro, op. cit., str. 336.

${ }^{9}$ Slobodan Samardžić, „Evropska unija - od dobrovoljnog saveza do 'dobre' imperije”, Otisak iz GLASA CDXXVI Srpske akademije nauka i umetnosti, Odeljenje društvenih nauka knj. 32, Beograd, 2016, str. 52.

${ }^{10}$ Delovi ovog poglavlja preuzeti su iz master rada Branimira Gajića pod naslovom „Mere Evropske centralne banke i kriza u Evrozoni”, odbranjenog na Fakultetu političkih nauka Univerziteta u Beogradu juna 2016. godine. Preuzeti tekst je prilagođen.

${ }^{11}$ Ova opservacija koja je sa zaoštravanjem bankarske krize često ponavljana, i koju je Evropska komisija prisvojila, pripisuje se bivšem guverneru Engleske centralne banke Mervinu Kingu (Mervyn King).
} 
često biva - jednom kada se iluzija mehura na finansijskim tržištima raspršila, banke su se suočile sa ogromnim gubicima. Sa dolaskom finansijske krize na evropsko tlo, države članice su bile prinuđene da emitovanjem obveznica finansijski podrže posrnule banke, što se potom odrazilo na rast njihovog javnog duga. U ovom kontekstu, kao opasnost se pojavio problem velikih finansijskih institucija koje su od isuviše velikog značaja da bi bile puštene niz vodu (too big to fail), a cenu čijeg opstanka su na kraju snosili poreski obveznici njihove zemlje porekla. Samo na početku krize, u periodu od 2008. do 2011. godine, države članice su odobrile ukupno 4,5 hiljade milijardi evra (36,7\% BDP Unije) pomoći bankama. ${ }^{12}$ Upravo radi „hvatanja u koštac” sa ovim problemima pokrenut je projekat Evropske bankarske unije kao ključni korak ka kompletiranju „prave” EMU. Iako ona, po preovlađujućem mišljenju, neće odista biti efektivna bez centralizacije fiskalnog upravljanja na evropskom nivou vlasti.

U uticajnom radu iz 2011. godine, ekonomista Dirk Schoenmaker uvodi koncept tzv. finansijske trileme koji implicira da nije moguće istovremeno ostvariti finansijsku stabilnost i finansijsku integraciju (prekogranično bankarstvo) uz zadržavanje nacionalne finansijske regulative. ${ }^{13}$ Bilo koja dva, od tri pomenuta, ekonomska cilja je moguće kombinovati, ali sva tri zajedno su nekompatibilna i predstavljaju destabilišući faktor koji doprinosi finansijskim krizama. Imajući u vidu specifičnosti evropske integracije, ovaj autor nalazi dva moguća rešenja za probleme u evrozoni. Prvo bi bilo preokrenuti ostvareni nivo integracije, odnosno odreći se dobrog dela integracije u finansijskom domenu zarad nacionalne kontrole. Druga dostupna opcija koju on označava kao „logično zaključenje finansijske trileme” sastoji se u centralizaciji finansijskih politika (kontrola, nadzor, stabilnost) na evropskom nivou. ${ }^{14}$

Kako je Schoenmaker u svojim radovima pažnju većim delom usmerio ka rizicima upravljanja globalnim bankarstvom, pojedini teoretičari su njegovo učenje prilagodili situaciji u zoni evra. Još jedan, četvrti element je morao biti uzet u obzir - zajednička valuta (jedinstvena monetarna vlast). Tako, u radovima teoretičara koji su u fokus stavili evropsku bankarsku krizu „trilema” prerasta u „nekonzistentni kvartet”. ${ }^{5}$

\footnotetext{
${ }^{12}$ Branko Vasiljević, Ratko Radosavljević, „Integracija bankarskog tržišta Evropske unije i formiranje bankarske unije", Pravo i privreda, br. 4-6, 2013, str. 282.

${ }^{13}$ Videti: Dirk Schoenmaker, "The Financial Trilemma", Tinbergen Institute Discussion Paper, Amsterdam (Duisenbeg School of Finance), kao i potonju knjigu istog autora koja je proistekla iz ovog članka - Governance of International Banking: The Financial Trilemma, Oxford University Press, 2013.

${ }^{14}$ Opširnije u: Dirk Schoenmaker, “The Financial Trilemma”, Economic Letters, No. 111 (2011), pp. 57-59.

${ }^{15}$ Detaljnije videti u: David Howarth and Lucia Quaglia, “The Steep Road to European Banking Union: Constructing the Single Resolution Mechanism", Journal of Common Market Studies, Vol. 52, Annual Review, pp. 127-128, 2014.
} 
S jedne strane, zajednička evropska valuta je osnažila finansijsku (uključujući i bankarsku) integraciju u Evrozoni koja je bila praćena ogromnim uzletom u prekograničnim bankarskim aktivnostima. S druge strane, uvođenjem evra nacionalne centralne banke su izgubile važnu funkciju ,kreditora u poslednjoj istanci”, a da pritom ona formalno nije preneta na nadnacionalnu ECB. Tako banke koje su svoje profite ostvarivale na otvorenom evropskom tržištu kapitala, sa dolaskom krize nije imao ko da podrži osim njihovih nacionalnih vlada. One su pri tome morale da odstupe od evropskih fiskalnih ograničenja zacrtanih u Paktu stabilnosti i rasta, pretvarajući bankarsku krizu u daleko opasniju dužničku.

Primenjujući Šoenmakerove teorijske premise na situaciju u kojoj se Evrozona našla po dolasku finansijske krize na njeno tlo, dolazi se do sledećeg zaključka: ukoliko članice žele da se prekogranično bankarstvo nastavi, a da istovremeno obezbede finansijsku stabilnost celokupnog sistema, one moraju prihvatiti nadnacionalnu prudencionu regulativu i sve što iz nje proizilazi. Zatim, kako bi se izbegao moralni hazard povezan sa funkcijom „kreditora u poslednjoj instnaci” za banke Evrozone, koju je tokom krize ECB prisvojila, mora joj se omogućiti posed sveobuhvatnih informacija u vezi sa poslovanjem banaka, a zatim i ovlašćenje da na neki način "disciplinuje” one koje su zapale u probleme (poput odluke o tome da li će biti dokapitalizovane ili puštene da bankrotiraju). Pritom, kako bi se tokom kriza izbegla panika i odliv kapitala (tzv. "juriš na depozite”), depoziti moraju biti zaštićeni jednako u svim članicama. Nadnacionalna Bankarska unija je, dakle sine qua non održivog ekonomskog upravljanja Evrozonom. Cilj koji stoji iza njenog uspostavljanja je jasan - sprečiti da posrnule banke ubuduće (ili preciznije, nanovo) ugroze stabilnost celokupne ekonomije Evrozone.

\section{4) TRNOVIT PUT DO BANKARSKE UNIJE - SUPROTSTAVLJENA GLEDIŠTA DRŽAVA ČLANICA ${ }^{16}$}

Drugu polovinu 2012. godine obeležile su rasprave i intenzivni međudržavni pregovori oko načina konstituisanja Bankarske unije. Efektivna ili potpuna Bankarska unija bi trebalo da obuhvata tri gradivna elementa (ili „stuba”, kako se ustalilo u terminologiji evropskih studija): nadnacionalni nadzor nad poslovanjem ključnih banaka u Evrozoni, centralizovano odlučivanje o eventualnoj likvidaciji banaka (uključujući zajednički fond iz koga bi se obezbedila potrebna sredstva za sanaciju banaka), kao i nadnacionalnu odgovornost za bankarske depozite.

Tokom pregovora, glavne pristalice dalekosežnijeg pristupa i bržeg napretka bile su Francuska, Italija, Španija, uz podršku nadnacionalnih institucija - Komisije i ECB. Nemačka kao najjača ekonomija Evrozone plašila se da će ukoliko popusti

${ }^{16}$ Delovi ovog poglavlja su preuzeti iz master rada Branimira Gajića „Mere Evropske centralne banke i kriza u Evrozoni". 
njihovim pritiscima vrlo brzo postati glavni kontributor budućeg fonda za spasavanje banaka. Na stranu Nemačke stale su Holandija i Finska, ističući rezerve prema planovima za dosezanje Bankarske unije. ${ }^{17}$ Istorija evropskih integracija nas uči da su širi interesi i ciljevi Nemačke i Francuske (politički, ekonomski, bezbednosni i dr.), ali i postignuti kompromisi i političke nagodbe tako duboko ugrađeni u konstrukciju evropskog projekta, da ne čudi što je upravo njihov dogovor bio potreban kako bi se krenulo napred. Zvanično, Francuska je podržavala Bankarsku uniju usled potrebe za delotvornijim nadzorom nad poslovanjem banaka, jedinstvenim mehanizmom garancije depozita u Evrozoni i zajedničkim fondom koji bi olakšao pritisak tržišta u pogledu nestabilnih banaka na „periferiji” Evrozone koje drže deo javnog duga evropskih vlada. ${ }^{18}$ Međutim, pravi interes Francuske za novi integracioni poduhvat je u znatnoj meri proisticao iz njene želje da se ustanovi određeni vid fiskalnog osiguranja i podrške (fiscal backstop) na nivou Evrozone. ${ }^{19}$ Time bi odgovornost (i troškovi) spasavanja posrnulih banaka bili raspodeljeni, tj. oni bi umesto sa nacionalnih vlada prešli na celinu Evrozone. A najveće (solidarne) izdatke bi, sledstveno, trebalo da podnesu ekonomski najjače članice. Indirektno, predsednici evropskih institucija (Evropskog saveta, ECB, Komisije) podržali su nastojanja francuske vlade, objavljivanjem pomenutog programskog dokumenta „Ka pravoj EMU” u koji su ugrađena određena rešenja bliska francuskim preferencama. Isprva, tvrdokoran stav tadašnjeg nemačkog ministra finansija da je Bankarska unija za Nemačku jedino prihvatljiva ukoliko je praćena fiskalnom unijom, čijim ustanovljavanjem bi se „nacionalne države odrekle jurisdikcije nad fiskalnom politikom", 20 je od 2012. godine naovamo osetno ublažen u smeru postepenog prihvatanja dela predloga članica i nadnacionalnih institucija zainteresovanih da Bankarska unija što pre ugleda svetlost dana i profunkcioniše. Iako je Nemačka pristala na određene koncesije, njeni predstavnici su u javnim istupima u više navrata jasno stavili do znanja da se protive objedinjavanju duga, ${ }^{21}$ prikrivenim fiskalnim transferima, a nadasve odgovornosti nemačkih poreskih obveznika za spasavanje stranih banaka ili garanciju bankarskih depozita u drugim članicama EU.

${ }^{17}$ David Howarth and Lucia Quaglia, "The Steep Road to European Banking Union: Constructing the Single Resolution Mechanism", op. cit., p. 128.

${ }^{18}$ David Howarth and Lucia Quaglia, "Banking Union as Holy Grail: Rebuilding the Single Market in Financial Services, Stabilizing Europe's Banks and 'Completing' Economic and Monetary Union”, Journal of Common Market Studies, Vol. 51, Annual Review, 2013, p. 111. ${ }^{19}$ Ibid.

20 „Bez fiskalne unije ne možemo prihvatiti zajedničku odgovornost za dugove.” SPIEGEL Interview with Finance Minister Schäuble 'We Certainly Don't Want to Divide Europe', 25.06.2012, Internet, https://www.spiegel.de/international/europe/finance-ministerschaeuble-euro-crisis-means-eu-structures-must-change-a-840640.html, pristupljeno 10.5.2020. god. 
Izvestan preokret u nemačkoj poziciji nastupio je kada je bankarska kriza ozbiljno uzdrmala Španiju i zapretila Italiji. Nedugo nakon što su američke agencije za kreditni rejting snizile rejting Španije i Italije, snižen je i rejting šest velikih nemačkih banaka, usled „uvećanog rizika od daljih šokova koji proističu iz dužničke krize u Evrozoni".22 U tom smislu, potonja pomoć Španiji za sanaciju njenog bankarskog sektora predstavljala je i rasterećenje za nemačke banke. Urgentnost situacije u Evrozoni je dovela do toga da Nemačka ublaži svoju poziciju, prihvatajući, prvo samostalno antikrizno angažovanje ECB (koja je preuzimajući na sebe nove uloge sve manje sličila uzoru po kom je nastala - nemačkoj Bundesbanci), a potom i projekat Bankarske unije (zadržavajući ipak najjaču pregovaračku poziciju u procesu međudržavnog nadmetanja). ${ }^{23}$

Među državama članicama takođe se povela polemika o tome koje će banke podleći direktnom nadzoru od strane ECB i načinima ostvarivanja te kontrole (odnos između nacionalnih i nadnacionalnih supervizorskih vlasti). ${ }^{24}$ Nemačka vlada se zalagala da centralizovanim nadzorom budu obuhvaćene samo sistemski važne prekogranične banke, uz poveravanje ECB nadležnosti vršenja finansijskih istraga i revizije. Nemačka je po svaku cenu nastojala da zadrži nadzor nad svojim štedionicama (sparkassen), koje su u godinama koje su prethodile finansijskoj krizi dosta ulagale u nesigurne drugorazredne hipotekarne kredite. Francuska, podržana od strane Komisije zalagala se da ECB pripadne pravo kontrole nad svim bankama (njih oko 6.000) u Evrozoni. Takođe, ona se zalagala (ovoga puta bez podrške Komisije) za uvođenje „sistema licenci” koji bi dozvolio nacionalnim supervizorima da deluju u ime ECB.$^{25}$ Do kraja 2012. godine, načelni dogovor u vezi sa Jedinstvenim nadzornim mehanizmom je postignut na najvišem nivou - u Evropskom savetu. Na stav Parlamenta i usvajanje konačnog teksta uredbe u Savetu se čekalo do oktobra 2013.

U leto 2013. Komisija je iznela predlog uredbe u vezi sa drugim stubom Bankarske unije - Jedinstvenim mehanizmom sanacije (Single Resolution Mechanisam), kao logičnim sledom i komplementarnim elementom prvodogovorenog Jedinstvenog

${ }^{21}$ Engleska reč mutualization se u literaturi prevodi na različite načine, kao objedinjavanje, pozajedničavanje, socijalizacija, ili pak mutualizacija duga.

${ }^{22}$ Opširnije u: Arie Krampf, "From the Maastricht Treaty to Post-crisis EMU: The ECB and Germany as Drivers of Change", Journal of Contemporary European Studies, Vol. 22, Issue 3, 2014, pp. 313-314.

${ }^{23}$ Opširnije o poziciji Nemačke tokom krize, videti u: Dragana Dabić, „(Ne)ograničeni uticaj Nemačke u Evrozoni: opstanak zajedničke valute iz ugla istorijskog institucionalizma", Međunarodni problemi, godina LXVIII, br. 4, 2016.

${ }^{24}$ Više o tome videti u: David Howarth and Lucia Quaglia, "Banking Union as Holy Grail: Rebuilding the Single Market in Financial Services, Stabilizing Europe's Banks and 'Completing' Economic and Monetary Union', op. cit., pp. 112-113.

${ }^{25}$ Ibid. 
nadzornog mehanizma. Najveće neslaganje među članicama bilo je u pogledu načina na koji bi se punio zajednički fond iz koga bi se obezbeđivala sredstva, bilo za pomoć bankama koje zapadnu u probleme, bilo za njihovu likvidaciju. Nemačka, svesna činjenice da se od nje traži da, srazmerno svojoj ekonomskoj snazi, podnese najveći finansijski teret u budućem fondu (ako ne neposredno, putem fiskalnih transfera i novcem njenih poreskih obveznika, onda posredno putem bankarskih uloga), nastupala je veoma oprezno. Interes Nemačke za ustanovljavanjem nadnacionalnog evropskog fonda je takoreći zanemarljiv, s obzirom da se radi o ekonomski veoma jakoj i, najvažnije, solventnoj državi, za koju je malo verovatno pretpostaviti da bi se suočila sa poteškoćama u slučaju potrebe za spasavanjem neke od domaćih banaka. ${ }^{26}$ Međutim, ne sme se ni u jednom trenutku zaboraviti da je od uznapredovale ekonomske integracije i uspostavljenih veza međuzavisnosti među državama Evrope u okvirima EU verovatno najveće koristi pobrala upravo Nemačka. Eventualni finansijski kolaps Evrozone bi sasvim sigurno rezultirao negativnim posledicama po njenu najjaču ekonomiju. Zatim, kada je na red došlo pitanje konačnog autoriteta koji će odlučivati o odobravanju ili uskraćivanju finansijske pomoći posrnuloj banci, izdvojila su se dva suprotstavljena stanovišta. Komisija je, logično, želela da prisvoji za sebe ovo ovlašćenje. Ovakav ishod je priželjkivala i Francuska. Suprotno, Nemačka se zalagala da krajnju odluku o tome da li će određena banka biti likvidirana donose države članice, koje bi uz to zadržale pravo veta. Kao tačka spoticanja izdvojila se i jedna lako zamisliva potencijalna situacija i, sledstveno postavljeno pitanje - šta bi se dogodilo ukoliko sredstva iz budućeg fonda ne budu dovoljna za spasavanje određenog velikog bankarskog sistema? Nemački zvaničnici su bili stava da bi, u tom slučaju, zemlja porekla banke trebalo da pokrije ostatak troškova. Francuska i južne članice Evrozone su se pak zalagale da bi za tu svrhu trebalo iskoristiti sredstva iz Evropskog stabilizacionog mehanizma. ${ }^{27}$

Kompromisno rešenje u pogledu Evropske bankarske unije nije zadovoljilo preference uključenih aktera. Nemačka je morala da pristane na mnogo više nego što je to isprva želela, ${ }^{28}$ a Francuska (i druge članice, kako one najteže pogođene

\footnotetext{
${ }^{26}$ Naime, sa izuzetkom jedne izrazito velike i veoma internacionalizovane komercijalne banke (Deutsche Bank), i druge, takođe velike banke sa značajnim evropskim prisustvom (Commerzbank), većina nemačkih banaka su primarno delovale unutar nacionalnih granica. Detaljnije u: David Howarth and Lucia Quaglia, "The Steep Road to European Banking Union: Constructing the Single Resolution Mechanism", op. cit., p. 131.

${ }^{27}$ Jim Brunsden and Rainer Buergin, "EU Stumbles Toward Bank Plan Deadline as Germany Resists", Bloomberg, November 15, 2013, Internet, https://www.bloomberg.com/news /articles/2013-11-14/germany-digs-in-against-risk-sharing-in-eu-bank-failure-debate, pristupljeno 10.5.2020.

${ }^{28}$ „Grubo rečeno, nemačkoj vladi se nimalo nije dopadalo što će morati da plati za zatvaranje stranih banaka i što će stranci moći da odlučuju o zatvaranju nemačkih banaka." David Howarth and Lucia Quaglia, "The Steep Road to European Banking Union: Constructing the Single Resolution Mechanism”, op. cit., p. 138.
} 
krizom tako i zastupnice ambicioznijih rešenja) nisu dobile ono čemu su se nadale - jasnu garanciju nacionalne finansijske stabilnosti, čak i kada je poljuljano poverenje u domaće banke. U literaturi je projekat evropske bankarske unije uglavnom označen kao nepotpun iz razloga što: prvo - ne obuhvata sve članice EU (potencira polemiku o Evropi u „više brzina”); drugo - kapacitet zajedničkog fonda za izmirenje dugova banaka bi se vrlo lako mogao pokazati kao nedovoljan; i treće - jasna nadnacionalna odgovornost za depozite još uvek nije ostvarena.

\section{5) TRI STUBA BANKARSKE UNIJE}

\subsection{JEDINSTVENI MEHANIZAM NADZORA (SUPERVIZIJE) BANAKA}

Tokom 2014. godine ECB je na sebe preuzela zadatak i odgovornost supervizije značajnih banaka i drugih kreditnih institucija na teritoriji članica Evrozone, uključujući i članice EU koje bi odlučile da pristupe Jedinstvenom mehanizmu nadzora. Ustanovljavanjem prvog stuba Bankarske unije došlo je do centralizacije prudencione kontrole na evropskom nivou. ${ }^{29}$ Ova mogućnost predviđena je Lisabonskim ugovorom, te je kao pravni osnov iskorišćen čl. 127, stav 6 Ugovora o funkcionisanju EU, u kome se kaže da: „Savet, odlučujući u skladu sa posebnom zakonskom procedurom, jednoglasno, i posle konsultovanja Evropskog parlamenta i ECB, može poveravati specifične zadatke ECB u vezi sa politikama iz oblasti kontrole kreditnih institucija i drugih finansijskih organizacija, sa izuzetkom preduzeća iz oblasti osiguranja". Da je reč o osetljivoj oblasti gde države ne gledaju blagonaklono na uplitanje nadnacionalnih institucija govori politički uslov jednoglasnosti (za razliku od redovnog zakonodavnog postupka koji predviđa usvajanje odluka u Savetu kvalifikovanom većinom), kao i okolnost da su jedino članice Evrozone obavezne da svoje banke prepuste nadnacionalnom nadzoru. Zemlje EU koje još uvek nisu prihvatile evro, mogu izabrati da učestvuju putem „bliske saradnje” sa ECB. ${ }^{30}$ Trebalo bi napomenuti da još uvek nijedna zemlja članica van Evrozone nije pristupila Jedinstvenom mehanizmu nadzora. Uprkos činjenici

\footnotetext{
${ }^{29}$ Prudenciona kontrola poslovanja banaka pretpostavlja ispitivanje rizičnosti poslovanja i adekvatnosti kapitalne osnove banaka. Ona takođe uključuje i zaštitu korisnika bankarskih usluga od arbitrarnih poslovnih odluka banaka, kao i operativnih rizika koji mogu imati posledice po korisnike (bankarske zloupotrebe). Milenko Dželetović, Ljubomir Šubara, Evro i monetarna integracija Evrope, Institut za međunarodnu politiku i privredu, Beograd, 2017, str. 239.

${ }^{30}$ Videti: "Decision of the European Central Bank of 31 January 2014 on the close cooperation with the national competent authorities of participating Member States whose currency is not the euro", (ECB/2014/5).
} 
da je pristupanje ovom mehanizmu uslov da mogu da zatraže finansijsku pomoć iz Evropskog stabilizacionog mehanizma. Da li onda to znači da članice koje još uvek nisu uvele zajedničku valutu veruju da su ozbiljnije finansijske nedaće povezane sa članstvom u Evrozoni? Da li je njihova trenutna procena da im finansijska pomoć iz zajedničkog evropskog fonda neće ni biti potrebna ukoliko se uzdrže od dalje integracije u ekonomskom domenu?

Preuzimanjem dodatnih nadležnosti očekuje se da ECB doprinese „sigurnosti i pouzdanosti kreditnih institucija, kao i stabilnosti finansijskog sistema u okviru EU i u svakoj njenoj članici". ${ }^{11}$ U cilju efikasnog izvršavanja poverenih joj zadataka, Uredbom se ECB garantuje nezavisnost, kako od nepriličnog političkog uticaja, tako i od mešanja industrije koje bi dovelo u pitanje njenu operativnu nezavisnost.

ECB trenutno direktno nadzire poslovanje 117 „najznačajnijih” banaka, na koje otpada oko $82 \%$ ukupne bankarske aktive evrozone. ${ }^{32}$ Prema predmetnoj Uredbi (čl. 6, stav 4), značaj se procenjuje na osnovu tri kriterijuma: veličini banke, važnosti za ekonomiju Unije ili bilo koje države članice koja učestvuje u Jedinstvenom mehanizmu nadzora i značaju njenih prekograničnih aktivnosti. Uredba precizira svaki od navedenih kriterijuma. Bez obzira na utvrđene kriterijume, ECB u svakom slučaju nadgleda poslovanje tri najveće banke u svakoj članici Evrozone, kao i sve banke koje zatraže ili prime pomoć iz Evropskog stabilizacionog mehanizma. Preostale banke podležu indirektnom nadzoru, tj. nadgledanje njihovog poslovanja nastaviće da vrše nacionalne vlasti, ali pod opštim uslovima utvrđenim od strane ECB. Dakle, prvi stub Bankarske unije je omogućio uspostavljanje homogenih standarda nadzora u okviru Evrozone.

Da bi ispunila novi mandat ECB ima na raspolaganju tri ključna instrumenta: prvo - odgovornost za licenciranje više od 6.000 kreditnih institucija; drugo sposobnost da nameće prudencione standarde kreditnim institucijama sa direktnim implikacijama u pogledu njihovog menadžmenta; i, napokon nadležnost da sastavlja supervizorske izveštaje kreditnih institucija u kojima ocenjuje „kvalitet” njihove aktive (tzv. stress test). ${ }^{33}$ Značajno je naglasiti da će ove provere uzeti u obzir i potencijalni rizik koji sa sobom nosi držanje vladinih obveznica u portfoliju banke, što ranije nije bio slučaj. ${ }^{34}$ Sve ovo, uzeto zajedno, pokazuje da su ECB poverena nova široka regulatorna ovlašćenja.

31 "Council Regulation (EU) No 1024/2013 of 15 October 2013 conferring specific tasks on the European Central Bank concerning policies relating to the prudential supervision of credit institutions", Official Journal 287/6.

${ }^{32}$ European Central Bank, Single Supervisory Mechanism, Internet: https://www.banking supervision.europa.eu/about/thessm/html/index.en.html, pristupljeno 11.3.2020.

${ }^{33}$ Videti: Dermot Hodson, "Eurozone Governance: Recovery, Reticence and Reform", Journal of Common Market Studies, Annual Review, Vol. 52, 2014, p. 193.

${ }^{34}$ Ibid. 
Kako deo teorijske misli, tako i pojedine države članice smatrale su da je njene nove regulatorne funkcije potrebno ograničiti (naročito je nemačka Vlada na tome insistirala) i posebno, razdvojiti od njene osnovne funkcije - jedinstvene monetarne vlasti za teritoriju Evrozone. Sukob interesa rešava se striktnom podelom nadležnosti u okviru organizacione strukture, odnosno odvajanjem unutrašnjih organizacionih delova ECB. ${ }^{35}$ Tako, umesto Izvršnom odboru (Executive Board) ECB, nove regulatorne funkcije su poverene novoformiranom Nadzornom odboru (Supervisory Board). Nadzorni odbor ima svog predsedavajućeg, njegovog zamenika, a u njegov sastav ulaze četiri predstavnika ECB i po jedan zvaničnik iz redova nacionalnih supervizora. Upravljačka struktura Nadzornog odbora ne samo što je glomazna, već je i osmišljena tako da ograniči moć Predsednika ECB, koji neće biti njen deo. ${ }^{36}$ Naime, u nadležnosti je Upravnog saveta (Governing Council) ECB (u kome, upravo guverneri nacionalnih centralnih banaka čine većinu) da predloži kandidate za predsedavajućeg i vicepredsedavajućeg, na osnovu otvorenog postupka selekcije, čiji izbor potom podleže odobrenju Evropskog parlamenta.

Ukratko, od novouspostavljenog nadnacionalnog mehanizma supervizije evropskih banaka se očekuje da ojača poverenje investitora u stabilnost evropskog bankarskog sektora, kao i da dogovoreni viši stepen integracije u finansijskom sektoru doprinese efektivnijem sprovođenju jedinstvene monetarne politike kao i boljem funkcionisanju EMU u celini.

\subsection{JEDINSTVENI MEHANIZAM SANACIJE BANAKA}

Iskustvo iz istorije evropskih integracija sugeriše da je za evropske države najteže da se usaglase oko sporazuma koji podrazumevaju "deljenje tereta”, naročito finansijskog. Tako je bilo i u slučaju finansijske potpore projekta Bankarske unije. Epilog je došao u vidu kompleksnog pravnog režima koji udružuje elemente nadnacionalnog odlučivanja i elemente međudržavnog sporazumevanja. Drugi stub Evropske bankarske unije temelji se na Uredbi o jedinstvenim pravilima i jedinstvenom postupku oporavka i sancije banaka. ${ }^{37}$ Takođe, prvenstveno na insistiranje Nemačke zaključen je Ugovor o prenošenju sredstava Jedinstvenom

\footnotetext{
${ }^{35}$ Milenko Dželetović, Ljubomir Šubara, Evro i monetarna integracija Evrope, op. cit., str. 241.

${ }^{36}$ Poređenja radi, Komitet za finansijsku politiku engleske centralne banke (Bank of England) broji samo 10 članova i na njegovom čelu se nalazi guverner. Dermot Hodson, "Eurozone Governance.: Recovery, Reticence and Reform", op. cit., p. 194.

37 "Regulation (EU) No 806/2014 of the European Parliament and of the Council of 15 July 2014 establishing uniform rules and a uniform procedure for the resolution of credit institutions and certain investment firms in the framework of a Single Resolution Mechanism and a Single Resolution Fund and amending Regulation (EU) No 1093/2010", Official Journal L 225/1.
} 
sanacionom fondu. ${ }^{38}$ Više puta tokom trajanja krize kada u Osnivačkim aktima nije mogao biti izdvojen jasan pravni osnov države članice su posegnule za sklapanjem međudržavnih sporazuma van evropskog prava.

Delujući kao kreditor u poslednjoj instanci, centralne banke obezbeđuju likvidna sredstva bankama koje su nelikvidne, ali solventne, dok se nesolventnost banaka rešava kroz mehanizam sanacije..$^{39}$ Jedinstveni mehanizam sanacije sastoji se iz dva ključna elementa: Jedinstvenog sanacionog odbora (centralizovano telo koje odlučuje) i Jedinstvenog sanacionog fonda koji se finansira od strane bankarskog sektora. Evropski zvaničnici očekuju da centralizovano upravljanje supervizijom i sanacijom velikih evropskih bankarskih sistema doprinese prekidanju negativne sprege između slabih banaka i kriza javnog duga koje prete da ugroze finansijsku stabilnost u zoni evra. Jedinstveni sanacioni fond iz koga će se uzimati sredstva, kako za spas banaka tako i za njihovo zatvaranje, osnovan je 1. januara 2016. god. Na početku se ovaj fond puni novcem iz doprinosa nacionalnih banaka. Međutim, Ugovor koji su među sobom potpisale države članice u vezi sa prebacivanjem sredstava Jedinstvenom sanacionom fondu predviđa postepeno (kroz osam godina) objedinjavanje sredstava, tj. udruživanje istih, koje briše razliku između nacionalnih doprinosa. Ovim će naposletku (doduše, u znatno ograničenoj formi) biti uvedena evropska pretpostavka odgovornosti za banke. U slučaju "gašenja" problematičnih banaka, njihove gubitke će najpre snositi akcionari i poverioci banaka, dok će u okviru trećeg stuba Bankarske unije štedni ulozi do visine od 100.000 evra biti osigurani. Time se nastojalo da umesto država, kako je to do sada bio slučaj, prvenstveno investitori snose rizik povezan sa njihovom investicionom odlukom. Banke na teritoriji Evrozone više nisu privilegovani akteri. Jedinstveni mehanizam sanacije je omogućio da „banke, isto kao i drugi sektori, budu podređene disciplini tržišta." ${ }^{\prime 0}$

Predviđena je mogućnost da Jedinstveni sanacioni fond pozajmljuje na tržištima kapitala. Međutim, ukoliko ostane bez sredstava Fond neće moći da računa na pozajmicu od Evropskog stabilizacionog mehanizma. Ovu okolnost jedan od vodećih ekonomista današnjice u oblasti evropskih studija Pol de Grove (Paul de

\footnotetext{
${ }^{38}$ Council of the European Union, Agreement on the transfer and mutualisation of contributions to the Single Resolution Fund, Brussels, EF 121 ECOFIN 342, 8457/14, 14 May 2014.

${ }^{39}$ Milenko Dželetović, Ljubomir Šubara, Evro i monetarna integracija Evrope, op. cit., str. 247. Sanacija banke (Bank resolution) je „poseban pravni režim za normalno restrukturisanje i/ili likvidaciju finansijskih institucija. Za takve institucije, opšta procedura stečaja nije pogodna, zbog njihove važnosti za privredu, postojanja sistemskog rizika i mogućnosti finansijske zaraze koja je specifična za finansijske aktivnosti, uključujući i banke". Navedeno prema: Ibid.

${ }^{40}$ Ann-Katrin Petersen, The Banking Union in a Nutshell, Allianz Global Investors, p. 4.
} 
Grauwe), prokomentarisao je na sledeći način: „Suština Bankarske unije je u vlasti sa finansijskim uticajem. Toga nema, tako da mi u stvari i nemamo bankarsku uniju" ${ }^{41}$ Ocene ekonomista su da oslanjanje isključivo na sopstvena sredstva koja poseduje Jedinstveni sanacioni fond (krajnja suma od oko 55 milijardi evra, što otprilike iznosi oko 1\% ukupne vrednosti bankarskih depozita na teritoriji država učesnica), neće ni približno biti dovoljno da se obuzda, eventualno, nova bankarska kriza velikih razmera. ${ }^{42}$

Kako izgleda postupak sanacije, odnosno likvidacije problematičnh banaka prema Uredbi o Jedinstvenom sanacionom mehanizmu? U prvom koraku, ECB (vršeći ranije poverenu joj funkciju nadzora), utvrđuje potrebu za sanacijom banke zemlje članice Bankarske unije. Ovaj početni okidač dodeljen, kako se pretpostvlja, neutralnim ekspertima ECB ograničava prostor za političko mešanje ministara država članica. U drugom koraku novoosnovano telo sa sedištem u Briselu pomenuti Odbor za sanaciju - procenjuje postojanje sistemskog rizika (u vidu potencijalne pretnje po javni interes) i razmatra eventualnu mogućnost alternativnih „privatnih” rešenja. Potom, u trećem koraku, Odbor izrađuje plan sanacije koji podnosi Komisiji. U poslednjem koraku, Komisija mora formalno da potvrdi odluku Odbora. Ona pri tome zadržava pravo veta (npr. u slučaju procene da bi principi zajedničkog tržišta bili narušeni). Savet ministara može, takođe, da se usprotivi planu rešenja ukoliko proceni da javni interes izostaje. A, ukoliko ni Komisija ni Savet ne ulože primedbe, odluka o sanaciji stupa na snagu u roku od 24 časa.

Postavlja se pitanje da li bi većina u Savetu možda mogla olako proceniti da javni interes izostaje kada je u pitanju pomoć banci neke od „perifernih” članica? Konkretne situacije će pokazati da li nastojanje da se zadovolje stavovi i interesi što više uključenih strana, podriva efikasnost samog mehanizma. Komentatori sa druge strane Atlantika najčešće su skloni da potcene domete evropske integracije. Makar deo razloga se krije u nastojanjima da tamošnjoj javnosti približe zamršeni evropski sistem upravljanja na više nivoa. Tako je tadašnji sekretar državnog trezora SAD, upitan da prokomentariše novine koje uvodi Jedinstveni mehanizam sanacije za evropske banke, jednostavno odgovorio: „Ne mislimo da je dovoljno veliko. $\mathrm{Ne}$ mislimo da je dovoljno brzo" ${ }^{43}$

${ }^{41}$ Navedeno prema: "EU negotiators reach deal to complete banking union", Euractiv, Mar 20, 2014, Internet, http://www.euractiv.com/sections/euro-finance/eu-negotiators-reachdeal-complete-banking-union-301022, pristupljeno 10.5.2020.

${ }^{42}$ Barry Eichengreen, "Europe's Crisis Treadmill”, Project Syndicate, May 12, 2014, Internet: http://www.project-syndicate.org/commentary/barry-eichengreen-takes-issue-withthose-who-claim-that-the-eurozone-crisis-is-over\#v38swZd7KSioBOfI.99, pristupljeno 10.5.2020.

${ }^{43}$ Navedeno prema: David Howarth and Lucia Quaglia, “The Steep Road to European Banking Union: Constructing the Single Resolution Mechanism”, op. cit., p. 137. 
Po svemu sudeći, drugi stub Evropske bankarske unije će u budućnosti biti poprište daljih institucionalnih reformi u smeru ka „pravoj” EMU, odnosno „više Evrope". Komisija nastoji da Bankarsku uniju inkorporira u ambiciozne planove o osnivanju Evropskog monetarnog fonda. Naime, u mapi puta za produbljivanje EMU, Komisija je predložila da budući Evropski monetarni fond, između ostalog, služi kao podrška Jedinstvenom sanacionom fondu pružanjem kreditne linije ili garancije u slučaju kada sanacija banke premašuje dostupna sredstva. ${ }^{44}$

\subsection{JEDINSTVENI MEHANIZAM OSIGURANJA DEPOZITA}

Evropska bankarska unija neće biti zaokružena bez dodavanja njenoj konstrukciji i poslednjeg potpornog stuba - panevropskog osiguranja bankarskih depozita. Nadnacionalni mehanizam garancije depozita na celoj teritoriji Evrozone nužan je kako bi se sprečila panika na finansijskim tržištima koju u vremenu krize izaziva masovno povlačenje depozita iz banaka, usled straha njihovih klijenata od kolapsa bankarskog sistema. Odmah valja napomenuti da se od samog začetka ideje o Bankarskoj uniji nije nazirao plan celovitog rešenja za njen treći stub. Glavni razlog je protivljenje Nemačke i njen stalni strah od nastanka situacije u kojoj će de facto postati glavni „finansijer” Evrozone. Imajući u vidu dosadašnje iskustvo sa (ne)nameravanim i/ili (ne)željenim posledicama integrativnih procesa, kao i funkcionalističku logiku širenja nadležnosti zajedničkih institucija (fenomen najizraženiji upravo u domenu ekonomske integracije), ne čudi njena nevoljnost ka daljoj centralizaciji ekonomskog upravljanja na evropskom nivou. ${ }^{45}$ Uprkos ambicioznim planovima evropskih zvaničnika i stalnim pozivima na reformu podupretim savetima ekonomista, garancija bankarskih depozita i dalje ostaje u nacionalnoj nadležnosti. Pravila u ovom domenu su harmonizovana putem Direktive o šemama garancije depozita. ${ }^{46}$

\footnotetext{
${ }^{44}$ Videti: "Communication from the Commission to the European Parliament, the European Council, the Council and the European Central Bank on further steps towards completing Europe's Economic and Monetary Union: a roadmap", Brussels, 6.12.2017, COM(2017) 821 final.

${ }^{45}$ Ipak, uvek bi trebalo imati u vidu ekonomsku korist koju Nemačka uživa od članstva u najtešnje integrisanom bloku. Ekonomista Martin Feldstein primetio je 2011. godine da je nemački trgovinski suficit grubo ekvivalentan udruženom trgovinskom deficitu Evrozone. Nemačka je za Evropu bila ono što je Kina za ostatak sveta - izvoznik koji zahteva od drugih da konzumiraju. Timothy Garton Ash, "The Crisis of Europe: How the Union Came Together and Why It's Falling Apart", Foreign Affairs, September/October 2012, Internet: https:// www.foreignaffairs.com/articles/europe/2012-08-16/crisis-europe, pristupljeno 10.5.2020.

46 "Directive 2014/49/EU of the European Parliament and the Council of 16 April on deposit Guarantee Schemes", Official Journal of European Union, L 173/149 of 12.06.2014.
} 
Prema predmetnoj Direktivi štedni ulozi u visini do 100.000 evra biće zaštićeni bilo gde u EU. Ratio legis Direktive ogleda se u zaštiti slobodne konkurencije na jedinstvenom tržištu. ${ }^{47}$ Naime, bilo je potrebno odrediti jedinstveni iznos zaštite depozita na nivou EU, kako bi se izbeglo prebacivanje novca u kreditne institucije zemalja sa boljim osiguranjem depozita. ${ }^{48}$ Sve države članice ustanovljavaju posebne fondove sa svrhom garancije depozita. Ovi fondovi će se puniti ex ante od strane banaka (što znači na regularnoj osnovi, a ne naknadno kada banka zapadne u probleme) u periodu od deset godina, sve dok ne dostignu nivo od 0,8\% ukupnih pokrivenih depozita (suma od oko 55 milijardi evra). Ukoliko se pokaže da je ovo nedovoljno, bankarski sektor će morati da obezbedi dodatne direktne (ex post) kontribucije. Direktiva predviđa mogućnost ustanovljavanja mehanizma koji bi dozvolio međusobno zaduživanje fondova za obezbeđenje depozita različitih članica EU na dobrovoljnoj osnovi. Kao važno pitanje od početka se nametnulo koliko brzo će štediše dobiti novac nazad u slučaju da banka zapadne u nevolje ili bankrotira? Prema rešenju u Direktivi, rok isplate depozita je sedam radnih dana od početka postupka likvidacije ili stečaja banke.

U cilju daljeg jačanja garancija depozita i samim tim osnaživanja finansijske stabilnosti na teritoriji Evrozone krajem 2015. godine Komisija je predstavila Evropski plan, odnosno šemu obezbeđenja depozita (European Deposit Insurance Scheme). Predložena je implementacija u tri razvojne faze u vremenskom periodu od 2017. do 2024. godine. ${ }^{49}$ Postepeno bi se kretalo od faze reosiguranja u kojoj bi Evropski mehanizam osiguranja depozita odobravao likvidnu podršku nacionalnim šemama osiguranja (pod strogim uslovima i samo do određenog nivoa), ka fazi koosiguranja koja znači progresivnu mutualizaciju (pozajedničavanje) obaveza, u kojoj bi evropski mehanizam snosio deo gubitaka u slučaju isplate depozita, da bi se naposletku dostigla faza punog osiguranja depozita na evropskom nivou. Finansiranje Evropske šeme obezbeđenja depozita obavljalo bi se iz već utvrđenih stopa doprinosa banaka koje učestvuju u napred pomenutim nacionalnim šemama, i to progresivnim povećanjem dela ovog doprinosa koji se prenosi na Evropsku šemu, tako da od treće faze sve uplate budu usmerene u jedinstveni Fond. ${ }^{50}$ Dakle, plan predviđa osnivanje zajedničkog Fonda za osiguranje depozita čime bi se rizik pokrivanja depozita prebacio u potpunosti na evropski nivo.

\footnotetext{
${ }^{47}$ Marko Dimitrijević, „Institucionalne osnove bankarske unije”, Pravo i privreda, 7-9/2016, Beograd, str. 280.

${ }^{48}$ Ibid.

${ }^{49}$ Videti: European Commission, "Proposal for a Regulation of the European Parliament and of the Council amending Regulation (EU) 806/2014 in order to establish a European Deposit Insurance Scheme", Strasbourg, 24.11.2015 COM(2015) 586 final.

${ }^{50}$ Milenko Dželetović, Ljubomir Šubara, Evro i monetarna integracija Evrope, op. cit., str. 258.
} 
Međutim, bez daljnjeg bi trebalo istaći da države članice još uvek nisu uspele da se usaglase oko uvođenja Evropske šeme obezbeđenja depozita, odnosno jasne pretpostavke nadnacionalne odgovornosti za depozite. Delovalo je da je politički proboj učinjen krajem 2019. godine kada je nemački ministar finansija objavio da je njegova zemlja spremna da podrži razvodnjenu verziju predloga Evropske šeme u vidu šeme za reosiguranje nacionalnih garancija za depozite. Ipak, ovaj pristanak bi bio dat tek pod uslovom pooštravanja regulatornog okvira upravljanja državnim dugom, što bi za banke značilo da moraju da povećaju svoje rezerve kapitala. ${ }^{51}$

Predstavljanje projekta bankarske unije u ovom radu zaključuje se jednom od uobičajenih konstatacija predstavnika EU: „Jednom kada budu uspostavljeni svi delovi bankarske unije, na bankama će biti da istraže i iskoriste sve prednosti evropskog tržišta. Tek tada se može utvrditi da li je bankarska unija zaista ispunila svoja obećanja." 52 Ovakva retorika se ustalila među briselskim birokratama i na najbolji način ilustruje moć i relevantnost zamisli evropskih „očeva osnivača” o „Evropi koja neće biti izgrađena odjednom” (npr. putem Ustava koji bi definisao federalno uređenje), već postepeno kroz „konkretna dostignuća”. Imajući u vidu da je zajedničko tržište jedno od najmanje spornih dostignuća integracije, većina poziva ka daljoj centralizaciji ekonomskih nadležnosti na naddržavnom nivou vlasti svodi se na dosezanje punog potencijala autentičnog evropskog političkog i ekonomskog prostora na kome su zagarantovane četiri slobode. ${ }^{53}$ Tako je i dublja integracija evropskog bankarskog sektora, tvrdi se, nužna kako ne bi došlo do fragmentacije zajedničkog tržišta. Baš kao što su i zagovornici evra pre par decenija tvrdili kako bi zajednička korist od unutrašnjeg tržišta bila potkopana kada bi države članice nastavile da koriste monetarnu politiku kao instrument prilagođavanje konkurentnosti. EMU je sagrađena na obećanju ekonomske konvergencije, rasta i napretka. Istorija evropske integracije pokazuje kako je potraga za najboljim načinom rešavanja problema uglavnom vodio ka „više Evrope”. Problem je, međutim, što je „više Evrope” gotovo uvek i odgovor na pređašnja neispunjena očekivanja.

\footnotetext{
${ }^{51}$ Videti u: Jorge Valero, “German plan brings 'new impetus' to banking union, Eurogroup says”, Euractiv, Nov 8, 2019, Internet, https://www.euractiv.com/section/bankingunion/news/german-plan-brings-new-impetus-to-banking-union-eurogroup-says/, pristupljeno 10.5.2020.

52 "Banking union, three years on - has it lived up to its promises?", Statement by Danièle Nouy, Chair of the Supervisory Board of the ECB, at the Single Resolution Board Conference, Brussels, 29 September 2017, Internet, https://www.bankingsupervision.europa.eu/press/ speeches/date/2017/html/ssm.sp170929.en.html, pristupljeno 10.5.2020.

${ }^{53}$ Reč je o slobodi kretanja ljudi, robe i kapitala, kao i slobodi pružanja usluga.
} 


\section{6) BUDUĆNOST EKONOMSKOG UPRAVLJANJA NA NIVOU EVROPSKE UNIJE - DA LI JE EVROPSKA BANKARSKA UNIJA "EMBRION FEDERALIZMA"? ${ }^{54}$}

Poučene gorkim iskustvom iz tridesetih godina prošlog veka (Velika depresija) veliki broj zemalja uveo je nove funkcije u svoje ekonomije sa ciljem stabilizacije u kriznim vremenima. Za ovaj rad od posebnog su značaja dve takve funkcije - uloga centralne banke kao kreditora u poslednjoj instanci i uvođenje automatskih stabilizatora budžeta. Tvorci EMU nisu predvideli postojanje antikriznih mehanizama i tu bi delom trebalo tražiti razloge zašto se upravo Evrozona našla na najjačem udaru krize. Važna pitanja poput utvrđivanja konkretnih mera koje bi trebalo da dovedu do uspešnog usaglašavanja nacionalnih ekonomskih politika ili načini na koji bi bili obezbeđeni kompenzatorni budžetski transferi u slučaju vanredih okolnosti su zaobiđena.

U akademskoj javnosti zastupljeno je stanovište da, iako se prethodno nisu obavezale na nadnacionalno ekonomsko upravljanje („ekonomsku vladu”), članice EU nije trebalo da kreću na neizvesni put centralizacije monetarne funkcije. Zašto onda, ukoliko bi se time rešio veliki deo ekonomskih problema sa kojima se EU suočava, jednostavno ne dođe do dalje centralizacije ključnih politika na evropskom nivou odlučivanja? Ova argumentacija uprošćeno tvrdi sledeće: „evro je valuta bez države; da bi se na duge staze održao, potrebno je stvoriti državu". ${ }^{55}$ Dalje napredovanje ekonomskih integrativnih procesa najveću prepreku ima u političkom karakteru Unije (u svim osetljivim oblastima, da bi odluka bila usvojena mora da zadovolji svih 27 članica Unije, ili makar svih 19 članica Evrozone), kao i u opadanju podrške javnog mnjenja njenim politikama. Evropske elite opasnost vide u mogućnosti da građani na referendumu odbiju dogovor postignut iza zatvorenih vrata, a ne bi trebalo zanemariti ni rast uticaja evroskeptičnih i antisistemskih partija.

Ekonomska i fiskalna unija bi podrazumevala korenitu izmenu načela i mehanizama na kojima EU počiva: direktne budžetske prihode, transfernu funkciju, uvođenje centralnog autoriteta zaduženog za formulisanje poreske politike itd. Sa jedne strane, ekonomski najjače članice EU nisu spremne da nastankom „transferne unije" preuzmu na sebe rizik da njihovi poreski obveznici u slučaju nove krize ponesu najveći finansijski teret. Pojedine članice možda ne bi bile dovoljno motivisane da pribegnu strukturnim reformama kada bi znale da mogu da računaju na finansijsku potporu. Ilustrativan primer je Belgijska federacija u kojoj su fiskalni transferi iz Flandrije ka Valoniji postali gotovo permanentni i, sledstveno,

\footnotetext{
${ }^{54}$ Žan Tirol, Ekonomija za opšte dobro, op. cit., str. 347.

${ }_{55}$ Paul de Grauwe, "Design Failures in the Eurozone: Can they be fixed?", Economic Papers 491/April 2013, p. 27.
} 
predstavljaju stalni izvor nezadovoljstva flandrijskih političara, ohrabrujući separatističke težnje.

Kako se dosezanje „istinske“ fiskalne unije, barem u skorije vreme, čini malo verovatnim, pojedini autori su stava da je plodotvorniji pristup istražiti politički moguće korake koji bi doveli do toga da EMU bolje funkcioniše i da za ubuduće razvije efikasnije antikrizne mehanizme. Prema Polu de Groveu, prva stvar koja je Evrozoni potrebna jeste delimično udruživanje odgovornosti nad javnim dugovima članica.$^{56}$ Kako bi se izbegla opasnost od moralnog hazarda (jake članice su nevoljne da na sebe preuzmu rizik plašeći se da će njihovo fiskalno „zdravlje“ i disciplina biti iskorišćeni od strane prezaduženih članica koje se neće previše truditi da smanje svoj dug i budžetski deficit) ovo udruživanje nacionalnih dugova trebalo bi da bude izvedeno sledeći unapred utvrđena pravila. Ono mora biti parcijalno, tako da značajan deo duga ostane u nacionalnoj odgovornosti kako bi Vlade država u pitanju i dalje ostale privržene politici fiskalne discipline. Zatim, De Grove smatra da bi trebalo obezbediti makar i delimičan kompenzatorski mehanizam od članica sa nižim kreditnim rejtingom ka onima čiji je kreditni rejting viši. Uz to, potrebno je nametnuti strogu kontrolu nad napretkom prezaduženih članica ka ostvarivanju održivih javnih finansija. U literaturi ima predloga koji idu tako daleko da zagovaraju postepeni gubitak autonomije u raspolaganju budžetom za najveće "grešnike” protiv evropskih budžetskih pravila. ${ }^{57}$ Ali, zar se time ne zagovara ekonomski protektorat nad članicama koje zapadnu u finansijske probleme? Takav sistem odnosa bi se verovatno pravdao konstatacijom kako oni koji su danas jaki, sutra mogu postati slabi i vice versa, a da pravila ostaju ista. Problem je, međutim, što u tom slučaju od izvornih načela osnivačkih ideala na kojim bi trebalo da se razvija „sve bliža Unija naroda Evrope” ne bi ostalo gotovo ništa. Najveći oponent izdavanju makar i limitiranog broja evroobveznica, kao zajedničkog instrumenta kojim se udružuju dugovi zemalja koje koriste evro, je nemačka kancelarka Angela Merkel. Ona strahuje da bi se tako udarili temelji onome što se u Nemačkoj javnosti percipira kao „dužnička unija” (Debt Union). ${ }^{58}$

Danas vidimo da je uvođenje zajedničke valute pojedine vlade u Evrozoni (naročito one koje su u prošlosti bile sklonije deficitarnom ponašanju) izložilo ogromnom riziku. Da li je moguće da su se one u trenutku dogovaranja monetarne unifikacije „kockale” sa zdravljem svojih ekonomija verujući da će protekom

\footnotetext{
${ }^{56}$ Opširnije u: Ibid., pp. 27-31.

${ }^{57}$ Predlaže se osnivanje Evropske agencije za dug. Videti: "Completing the Euro: A road map towards fiscal union in Europe", Report of the "Tommaso Padoa-Schioppa Group", 2012, p. 38.

${ }^{58}$ Matthias Matthijs and R. Daniel Kelemen, "Europe Reborn, How to Save the European Union From Irrelevance", Foreign Affairs, January/February 2015, Internet: https://www.foreign affairs.com/articles/europe/europe-reborn, 10/05/2020.
} 
vremena Nemačka ublažiti svoj stav u pogledu fiskalnih transfera ili niske inflacije? Jer, ukoliko deficitarne države poput Grčke i Italije ne bi uspele da ubede Nemačku da promeni svoje držanje, onda to znači da su igrale na kartu sopstvenih sposobnosti da usvoje nemačke standarde u pogledu discipline plata, javnog trošenja i međunarodne kompetitivnosti. ${ }^{59}$

Kriza je omogućila naddržavnom evropskom nivou da sebi pripiše nove nadležnosti. Kod upravljanja Evrozonom se ne radi samo o organizovanju tržišta, već je na delu usklađivanje ekonomskih politika, fiskalnih sistema i budžetskih politika nacionalnih država; ukratko, ušlo se u središte društvenih ugovora zemalja članica. ${ }^{60}$ Dve su ključne karakteristike postkriznog upravljanja: prvo - ono je naddržavno, jer prevazilazi sposobnost kontrole pojedinačnih članica, bile to i najjače članica bloka; i drugo - ono je nedemokratsko, u smislu da izlazak evropskih građana na birališta gotovo da nema uticaj na promenu vrhovne ekonomske strategije.

Dobitnik Nobelove nagrade za ekonomiju, Džozef Stiglic 2001. godine, u poslednjoj knjizi posvećenoj krizi evra, označio je valutni eksperiment u vidu uvođenja zajedničke evropske valute kao glavnog „krivca“ za eventualni slom evropskog projekta. Premisa od koje je pošao, a koja prizilazi iz njegovih ranijih teorija i koju je sada primenio na kontekst evrozone, jeste da ekonomska tržišta sama po sebi nisu efikasna. ${ }^{61}$ On iznosi smernice za tri alternative današnjoj strategiji suzbijanja efekata krize, koju označava kao „tumaranje”. U pogledu uslova koji bi trebalo da budu ispunjeni za dugoročni opstanak evra kao zajedničke evropske valute, Stigliceva poruka je nedvosmislena: „Ključne reforme neophodne su u strukturi same valutne unije, ne u privredama pojedinačnih zemalja". ${ }^{62}$ Dakle, upravo suprotno preovlađujućoj antikriznoj ekonomskoj strategiji evropskih elita.

Još jedan nobelovac Žan Tirol (nagrada za ekonomiju 2014. godine), smatra da bi bankarska kriza u Španiji bila izbegnuta da je tada postojala Bankarska unija. ECB, koja je danas nadležna za nadzor nad evropskim bankama, primorala bi španske banke da uspore sa svojim ulaganjem u nekretnine. ${ }^{63} \mathrm{Uz}$ to, ukoliko Bankarska unija bude podupreta evropskim osiguranjem štednih uloga kao garancije za depozite štediša u evropskim bankama, koje su i same predmet

\footnotetext{
${ }^{59}$ Andrew Moravcsik, "Europe after the Crisis", How to Sustain a Common Currency, Foreign Affairs, May/June 2012, Internet: https://www.foreignaffairs.com/articles/europe/201205-01/europe-after-crisis, 10/05/2020.

${ }^{60}$ Enet Stefani, et al., Za sporazum o demokratizaciji Evrope, Akademska knjiga, Novi Sad, 2017, str. 10.

${ }^{61}$ Džozef E. Stiglic, Evro: Kako zajednička valuta ugrožava budućnost Evrope, Akademska knjiga, Novi Sad, 2016, str. 16.

${ }^{62}$ Ibid., str. 10.

${ }^{63}$ Žan Tirol, Ekonomija za opšte dobro, op. cit., str. 330.
} 
centralizovanog nadzora, to će biti važan korak ka podeli rizika sa ograničenim moralnim hazardom za države članice koje više ne nadgledaju nacionalne banke. ${ }^{64}$ Domaći autori takođe poimaju bankarsku uniju kao uvođenje federativnih okvira u oblast bankarskih sistema, i kao logičnu dogradnju karike koja nedostaje u monetarnoj uniji kao federalnoj tvorevini. ${ }^{65}$ Više je činilaca koji su omogućili nastavak centralizacije na nivou EU, uprkos javnosti koja je izgubila veru u obećanja integracije. Slaba politička i medijska pokrivenost bankarskog nadzora olakšala je napuštanje suvereniteta putem stvaranja Bankarske unije. ${ }^{66}$ Prevaga tehnokratske racionalnosti dovela je do toga da u današnjoj EU subjekti bez demokratskog mandata mogu nametati rešenja bez alternative ${ }^{67}$ Posledica je umanjena spoznaja građana o razmeri transfera nadležnosti socio-ekonomskog odlučivanja i, sledstveno, ograničenje njihove demokratske autonomije.

Jedan od najdalekosežnijih ishoda krize u Evrozoni i institucionalnih odgovora na nju, jeste izuzetan položaj ECB u postkriznom sistemu upravljanja. Njena pozicija (i moć) unutar sistema nije uravnotežena. Kao rešenje uglavnom se zagovara centralizacija moći ministra finansija, koja bi zahtevala Evropsko ministarstvo finansija, a na taj način i evropsku vladu ${ }^{68} \mathrm{U}$ današnjoj Evrozoni, neformalno je na sebe tu ulogu pruzela Evrogrupa u kojoj su okupljeni ministri finansija članica. Međutim, ona ne odgovara niti Evropskom parlamentu niti direktno nacionalnim parlamentima, što se negativno odražava po interese građana Evrope. Strukture unutar kojih se koncentrisala politička moć tokom krize, a koje su opstale i po njenom okončanju, precenjuju ciljeve finansijske stabilnosti i „tržišnog poverenja”, potcenjujući istovremeno važnost politika koje se direktno tiču većine, poput zapošljavanja, privrednog rasta, socijalne povezanosti, solidarnosti itd. ${ }^{69}$

U svetlu teorijskih razmatranja značaja Bankarske unije unutar postkriznog upravljanja EU, nameće se nekoliko pitanja. Može li se zaobilaznim putem kroz ovaj projekat doći do evropske federacije? Preciznije, da li se davanjem prvenstva razlozima ekonomske nužnosti koji su ugrađeni u kompleksni i sofisticirani tehnokratski projekat upravljanja Evrozonom može izbeći politička odluka o

\footnotetext{
${ }^{64}$ Ibid., str. 347.

${ }^{65}$ Milenko Dželetović, Ljubomir Šubara, Evro i monetarna integracija Evrope, op. cit., str. 228.

${ }^{66}$ Žan Tirol, Ekonomija za opšte dobro, op. cit., str. 347-348.

${ }^{67}$ Lošonc Alpar, „Evropska unija i tehnokratsko starateljstvo”, Theoria 2, (2018): 61, str. 16.

${ }^{68}$ Ovakvo rešenje isprva je izneto u memorandumu britanskog ministarstva finansija naslovljeno „Evolutivni pristup ekonomskoj i monetarnoj uniji” iz 1989. godine. Navedeno prema: Milenko Dželetović, Ljubomir Šubara, Evro i monetarna integracija Evrope, op. cit., str. 134. Ono je, takođe, zastupljeno i u savremnoj ekonomskoj doktrini evropskih integracija.

${ }^{69}$ Enet Stefani, et al., Za sporazum o demokratizaciji Evrope, op. cit., str. 10.
} 
prenosu nadležnosti? Da li cilj opstanka evra opravdava poricanje demokratskog izbora evropskim građanima?

\section{7) ZAKLJUČAK}

Evropska bankarska unija izgrađena je ne bi li se postigla dva široka cilja. Prvi je, generalno učiniti evropske banke sigurnijim, dok je drugi dosezanje istinskog evropskog bankarskog sektora kao dela funkcionalne EMU. Važni koraci u tom smeru bili su postavljanje prva dva stuba konstrukcije - Jedinstveni mehanizam nadzora i Jedinstveni mehanizam sanacije banaka. Međutim, za Bankarsku uniju kakva je na delu ne može se reći da je ostvarila zacrtane ciljeve. Ona je nepotpuna. Kako bi bila dovršena potrebno je postaviti i treći stub - Evropski mehanizam osiguranja depozita. Danas se supervizija banaka, kao i njihova sanacija, vrše na evropskom nivou. Međutim, u slučaju eventualnog neuspeha negativne posledice se i dalje uglavnom prenose na nacionalni nivo.

Da li će u dogledno vreme biti izgrađena „istinska” ili „prava” EMU? Kada je u pitanju politički i ekonomski sistem poput EU (o karakteru čijeg uređenja i krajnjim ciljevima ne postoji saglasnost), trebalo bi uvek imati na umu njene specifičnosti. Reč je o mnogobrojnim političkim, pravnim i institucionalnim ograničenjima kao preprekama usvajanju mera koje bi se moguće pokazale opravdane sa ekonomskog aspekta. U slučaju EU, nikada ne treba zanemariti inhibirajući uticaj nemogućnosti dosezanja političkog dogovora o nečemu što bi se možda činilo kao ekonomski racionalno ili isplativo. Usled stalnog uvećanja njenog članstva (posledica čega je, uopšteno posmatrano, usložnjavanje društvenih prilika unutar evropskih tela), postalo je veoma teško definisati zajednički interes. Sledstveno, postizanje sporazuma koji podrazumeva deljenje obaveza ili veće odricanje nekih članica (npr. u vidu većih finansijskih doprinosa zajedničkim fondovima), deluje izrazito teško - gotovo nedostižno. Posledice toga su polovična, „mlaka” i nedovoljno efektivna rešenja na evropskom nivou vlasti. Bez političke volje da se ide napred i deli rizik, nema ni funkcionalnih zajedničkih ekonomskih institucija.

Imajući u vidu dosadašnje iskustvo sa zajedničkom valutom, opravdano je zaključiti da se u projekat evropske monetarne unifikacije ušlo isuviše ishitreno (i pored toga što su prvi planovi kovani još daleke 1969. godine na samitu u Hagu), bez prethodno ispunjenih uslova i sa prevelikim optimizmom da će zajednička valuta predstavljati istinsku prekretnicu u smislu nastavka evropskih integracija u fiskalnoj i političkoj oblasti. Usvojene mere zarad smirivanja krize na evropskom tlu jesu potencijalno dalekosežne u smislu stvaranja uslova za nastavak integracije u budućnosti. Sporazumevanje država članica uglavnom vodi ka rešenjima koja su oličena u politici „najmanjeg zajedničkog imenioca”. U ekonomskom domenu, nepotpuni i nedovršeni mehanizmi su se pokazali kao okidači kriza, nakon čega bi usledio zahtev za produbljenjem integracije. Međutim, ovaj inkrementalni razvoj će u jednom trenutku po svemu sudeći biti zaustavljen političkim odgovorom 
građana - bilo davanjem pristanka naddržavnom upravljanju, ili pak odbacivanjem sveukupnih kako dostignuća tako i izneverenih nada integracije. Što se tiče akademske misli, borba za demokratizaciju evropskog projekta uveliko traje.

\section{8) LITERATURA}

Lošonc, Alpar, „Evropska unija i tehnokratsko starateljstvo”, THEORIA 2, (2018): 61, str. 7-23.

Antevski, Miroslav, Rapaić, Stevan, „Kriza u Evrozoni i evropska integracija”, Evropsko zakonodavstvo, God XIII, br. 47-48, str. 92-121.

Dabić, Dragana, „(Ne)ograničeni uticaj Nemačke u Evrozoni: opstanak zajedničke valute iz ugla istorijskog institucionalizma", Međunarodni problemi, godina LXVIII, br. 4, 2016.

Dabić, Dragana, „Kriza Evrozone i dosadašnji odgovori Evropske unije, Evropsko zakonodavstvo, godina XIII, br. 47/48, 2014, str. 139-161.

De Grauwe, Paul, "Design Failures in the Eurozone: Can they be fixed?", Economic Papers 491/April 2013.

Dimitrijević, Marko, „Institucionalne osnove bankarske unije”, Pravo i privreda, 79/2016, Beograd.

Dželetović, Milenko, Šubara, Ljubomir, Evro i monetarna integracija Evrope, Institut za međunarodnu politiku i privredu, Beograd, 2017.

Enet Stefani, Piketi Toma, Sakrist Gijom, Voše Antoan, Za sporazum o demokratizaciji Evrope, Akademska knjiga, Novi Sad, 2017.

Garton Ash, Timothy, "The Crisis of Europe: How the Union Came Together and Why It's Falling Apart", Foreign Affairs, September/October 2012.

Hodson, Dermot, "Eurozone Governance: Recovery, Reticence and Reform”, Journal of Common Market Studies, Annual Review, Vol. 52, 2014.

Howarth, David and Quaglia, Lucia, "Banking Union as Holy Grail: Rebuilding the Single Market in Financial Services, Stabilizing Europe's Banks and 'Completing' Economic and Monetary Union", Journal of Common Market Studies, Vol. 51, Annual Review, 2013.

Howarth, David and Quaglia, Lucia, "The Steep Road to European Banking Union: Constructing the Single Resolution Mechanism", Journal of Common Market Studies, Vol. 52, Annual Review, 2014.

Janjević, Milutin (prir.), Konsolidovani Ugovor o Evropskoj uniji, Službeni glasnik, Beograd, 2009.

Krampf, Arie, "From the Maastricht Treaty to Post-crisis EMU: The ECB and Germany as Drivers of Change", Journal of Contemporary European Studies, Vol. 22, Issue 3, 2014. 
Majone, Giandomenico, Rethinking the Union of Europe Post-crisis: Has Integration Gone Too Far?, Cambridge University Press, 2014.

Matthijs, Matthias and Kelemen, Daniel R., "Europe Reborn: How to Save the European Union From Irrelevance", Foreign Affairs, January/February 2015.

Moravcsik, Andrew, "Europe after the Crisis", How to Sustain a Common Currency, Foreign Affairs, May/June 2012.

Samardžić, Slobodan, „Evropska unija - od dobrovoljnog saveza do 'dobre' imperije”, Otisak iz GLASA CDXXVI Srpske akademije nauka i umetnosti, Odeljenje društvenih nauka knj. 32, Beograd, 2016.

Schoenmaker, Dirk, “The Financial Trilemma”, Economic Letters, No. 111 (2011).

Schoenmaker, Dirk, "The Financial Trilemma", Tinbergen Institute Discussion Paper, Amsterdam (Duisenbeg School of Finance).

Stiglic, Džozef E., Evro - Kako zajednička valuta ugrožava budućnost Evrope, Akademska knjiga, Novi Sad, 2016.

Tirol, Žan, Ekonomija za opšte dobro, Akademska knjiga, Novi Sad, 2019.

Vasiljević, Branko, Radosavljević, Ratko, „Integracija bankarskog tržišta Evropske unije i formiranje bankarske unije", Pravo i privreda, br. 4-6, 2013. 


\section{EUROPEAN BANKING UNION AS PART OF THE POST-CRISIS GOVERNANCE SYSTEM OF ECONOMIC AND MONETARY UNION}

Summary: The paper examines the assumption that the project of building the European Banking Union represents the most significant transfer of economic competencies to the European Union since the decision on the centralization of monetary policy. The goal of the paper is twofold. The architecture of the Banking Union is considered first, primarily on the basis of the sources of European law. Thereafter, the broader implications of the integrated financial framework are considered, primarily expectations regarding further centralization of competences at the Union level. For now, the establishment of the first two pillars of the architecture of the Banking Union has been set up - the Single Supervisory Mechanism and the Single Resolution Mechanism. However, the Banking union with its current setup did not achieve the goals set by European statesmen and Union officials. It is still incomplete. In order to complete it, it is necessary to set up its third pillar - the European (supranational) deposit insurance mechanism. It is concluded that in the future, this project will be the playground for further institutional reforms in the direction of a "genuine" Economic and Monetary Union. The way in which the governance system in the euro area is definitely shaped, in terms of relations between the central level and the member states (federal principle versus return to lower levels of integration), as well as, relations between the members themselves (principle of democratic equality versus undemocratic pattern of superiority and subordination), will have crucial impact on the future of the European unification project. It is necessary to take further steps in order to legitimize relations between political actors, functioning of the institutions and insufficiently transparent supranational decision-making processes.

Keywords: Economic and Monetary Union, Banking Union, European Union crisis, post-crisis governance system, European Central Bank, supranational, economic governance, technocratic governance, democratic deficit, legitimacy. 